\title{
Experimental investigation of the wind direction influence on the cooling of photovoltaic panels integrated in double skin façades
}

\author{
Sebastian Valeriu Hudișteanu ${ }^{1, *}$ and Cătalin George Popovici ${ }^{1}$ \\ 1"Gheorghe Asachi" Technical University of Iaşi, Faculty of Civil Engineering and Building Services, Romania
}

\begin{abstract}
The paper presents a wind tunnel experimental investigation of a small-scale building model (1:30). The main objective of the study is to determine the influence of the reference wind direction over the ventilation inside the double skin façade (DSF) channel. The analyzed system consists of a building equipped with photovoltaic panels as the exterior glazing of DSF. The tests were achieved by conceiving and implementation of an experimental program using a wind tunnel with atmospheric boundary layer. The aim is to determine with acceptable probability the velocities that can be reached in the ventilated façade channel during the warm season and to establish a correlation between the external reference velocity magnitude and direction and the velocity field generated inside the channel of the façade. Measurements were carried out for the reference wind speed, total, dynamic and static pressure both in the reference point and inside the façade channel. The results of the investigation highlighted the correlation between the velocity and direction of the reference wind and the dynamics of the air movement inside the double skin façade. The measurements showed that for the analyzed configuration of the double skin façade, there is an optimal wind direction that ensures the best cooling effect to photovoltaic panels. Also, the convective heat transfer coefficients were determined under these conditions. The decrease of the photovoltaic panel's temperature determines a raise of its efficiency and generated power.
\end{abstract}

\section{Introduction}

The wind effect over buildings represents an important issue and it is most often studied using wind tunnel simulations. The exposure of buildings to the wind determines dynamic loads on the building's facades [1,2], snow accumulation on roofs [3] or natural ventilation of the indoor environment $[4,5]$. The study of the wind action over the buildings is characterized by a random behavior, caused by the air's velocity and direction.

In order to design the wind effect, the mean values for velocity and direction are necessary. The effect of the fluctuations, are determined using probabilistic theories and statistical distributions of the wind velocities and pressures. During experimental analysis, the values recorded continuously and discontinuously are used for calculating the 10 minutes average values and obtain the basic wind velocity [5].

The definition of the basic wind velocity, $v_{b}$, includes both the direction and season effects and it is measured at a $10 \mathrm{~m}$ height above the ground, with a probability of $2 \%$ of exceeding the annual average [5]. On the other hand, the mean velocity, $v_{m}(z)$, is also based on $v_{b}$, but varies with the height from the ground, $z$, with the roughness of the terrain and orographic particularities [6].

The basic wind pressure, $p_{b}$, can be expressed using the basic wind velocity, $v_{b}$ :

$$
p_{b}=\frac{\rho \cdot v_{b}^{2}}{2}(1)
$$

where, $\quad \rho$-air density at nominal temperature $\left[\mathrm{kg} / \mathrm{m}^{3}\right]$.

The average wind velocity maintains its dynamic and random character, while the spatial fluctuations of the instantaneous velocity have also an important role. The relation to express the instant velocity at the height $z$ above the ground has the following form:

$$
v(z)=v_{\text {med }}(z)+v^{\prime}(z)(2)
$$

where, $v_{\text {med }}(z)$ - average velocity on time interval $\tau[\mathrm{m} / \mathrm{s}]$; $v^{\prime}(z)$ - fluctuating velocity $[\mathrm{m} / \mathrm{s}]$.

Usually, the average value, $v_{\text {med }}(z)$, is a characteristic of the wind profile, while the fluctuating component, $v^{\prime}(z)$, is used for measuring the turbulence intensity and quantifies the maximum and minimum velocities.

For designing the wind action, the peak pressure, $q_{p}(z)$, becomes relevant, because it includes the effects of the random wind speed and pressure fluctuations. The peak pressure is obtained by using an exposure factor proportional to the height above the ground and the turbulence intensity.

The spatial variation of the wind velocity and direction, on horizontal and vertical planes, determines lower wind velocities in urban areas, but increased turbulence intensities, while the open fields are characterized by higher wind velocities and lower turbulence intensity [5], Fig. 1.

\footnotetext{
* Corresponding author: sebastian.hudisteanu@tuiasi.ro
} 


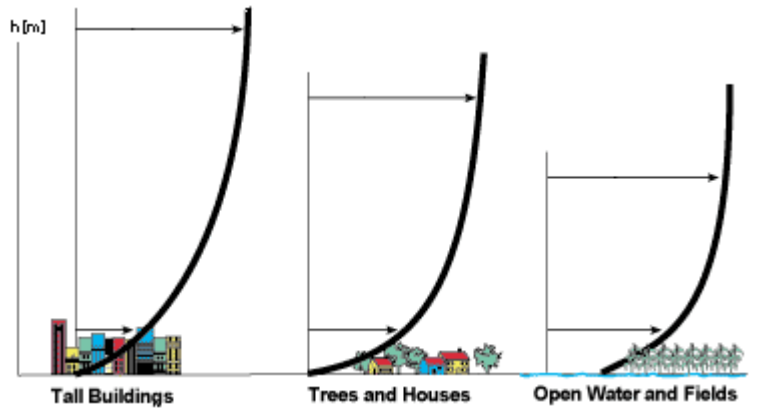

Fig. 1. Distribution of wind velocity on vertical plane [7].

Studies regarding the effect of wind on buildings with double skin façades [9-14] or building integrated photovoltaics systems $[1,15-17]$ provide both qualitative and quantitative data concerning the cooling effect of airstreams [18].

The action of the wind causes a dynamic pressure, which is increasing with the height [5], and has a favorable effect for the ventilation of double skin facades [9, 10], determining a series of local pressures and suctions. For velocities of $10 \mathrm{~m} / \mathrm{s}$ or higher, the flow becomes neutrally stable.

In order to determine the wind action on the buildings, it is recommended to use simulations in wind tunnels with turbulent boundary layer [6]. During these tests it is mandatory to identify and assure the similarity conditions between the model and prototype $[6,5]$.

The analysis made in wind engineering, showed that the inertial forces prevail, and the flow is a turbulent one, at very high Reynolds numbers $(\mathrm{Re})$. Studies regarding the simulations in wind tunnel showed that a self-modelling condition is accomplished when Re numbers reach values of $(0.5 \ldots 1.2) \cdot 10^{5}[5,19]$, which simplifies physical models and avoid the inconveniences in satisfying the similarity requirements. In case of objects with sharp edges, such as buildings, the similarity is ensured by self-modelling, being insensitive to the Re numbers [5].

The study was achieved by conceiving and implementing an experimental program in the atmospheric boundary layer wind tunnel. The current analysis is focused in determining with acceptable probability the velocities that can be reached in the ventilated façade channel during the warm season and to establish a correlation between the external reference velocity, measured under fixed conditions, and the velocity field generated inside the channel of the façade. The results for velocities are processed as average steady state values of 4 series of measurement of 30 seconds, resulting a total time of 2 minutes for each case. The frequency of measurement was set to 1000 values per second.

\section{Experimental setup}

The wind tunnel experimental analysis is targeted to a reduced scale (1:30) model of building equipped with ventilated double skin façade. The real building is a 3 stores structure of $13.5 \mathrm{~m}$ height and $12 \mathrm{~m}$ width. During this study it is considered that the outer layer of the double skin façade is composed of photovoltaic (PV) panels. The purpose of the study consists in determining the right orientation of the building related to the wind direction, for the analyzed type of double façade [5].

During the study, there is obtained with acceptable probability the air velocity inside double skin façade, near the PV panels, during hot season, correlated to the direction and magnitude of reference velocity.

The experimental measurements inside the channel of the double skin façade, are directed to the following parameters: reference wind velocity; dynamic, static and total pressures. The scale of the model $(1: 30)$ was chosen taking into account the transversal section of the wind tunnel, with following dimensions: $1.4 \mathrm{~m}$ height and 1.4 $\mathrm{m}$ width. In order to avoid blockage of the airflow in the cross section, the transversal projection of the building was reduced to a maximum of $10 \%$ of the wind tunnel's one, resulting an area of $0.196 \mathrm{~m}^{2}$. In these conditions, the building model has been constrained to the transversal dimensions of $0.40 \mathrm{~m} \mathrm{x} 0.475 \mathrm{~m}$, with an effective area of wind incidence of $0.19 \mathrm{~m}^{2}$. For this configuration, the width of the ventilated façade is $0.01 \mathrm{~m}$ for the model, corresponding to a $0.3 \mathrm{~m}$ on the real building.

The experimental model of the building is made of transparent plastic material and has the following components: building model, double skin façade (DSF), photovoltaic panels in front of DSF and the cover of the building, Fig. 2.

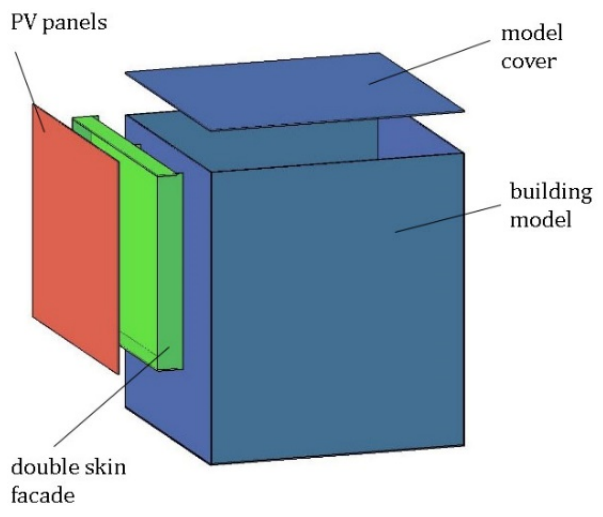

Fig. 2. Dimensions and components of the building with double skin façade.

For the experimental model, the external glazing of the double skin façade consists of photovoltaic panels, resulting a building integrated photovoltaic system (BIPV). The compartmentation on the full height of the double skin façade analyzed consist in 2 vertical channels divided into 3 horizontal ones. Inside the channels of the DSF, the air circulation due to wind action generates a cooling effect on the PV panels.

The wind tunnel testing program is based on the assumption that for the full-scale buildings the air circulates vertically and horizontally, determined by the temperature gradient and wind action, avoiding the overheating inside the channel. The main components and geometrical details of this configuration are displayed in Table 1 and Fig. 3 - Fig. 6. 
Table 1. Double skin façade channel.

\begin{tabular}{|c|}
\hline-6 inlet sections de $\left(S_{\text {in }}\right) ;$ \\
\hline-6 intermediate sections $\left(S_{\text {inter }}\right) ;$ \\
\hline-1 outlet section $\left(S_{\text {out }}\right) ;$ \\
\hline$-S_{\text {in }}=6 \mathrm{x}(5 \mathrm{x} 1)=30 \mathrm{~cm}^{2}$. \\
\hline$-S_{\text {inter }}=\mathrm{S}_{\text {in }}=30 \mathrm{~cm}^{2}$. \\
\hline$-S_{\text {out }}=1 \mathrm{x} 1=1 \mathrm{~cm}^{2}$. \\
\hline
\end{tabular}

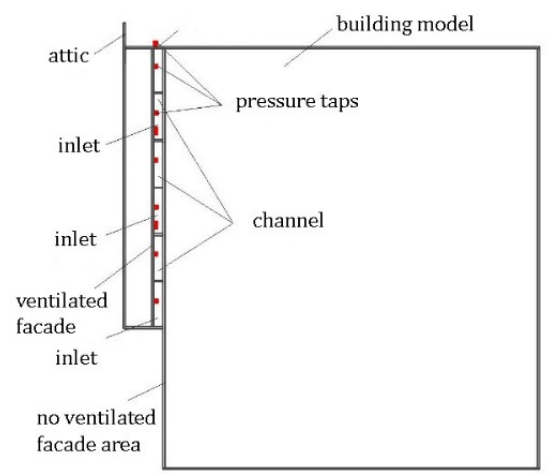

Fig. 3. Cross section through building model.

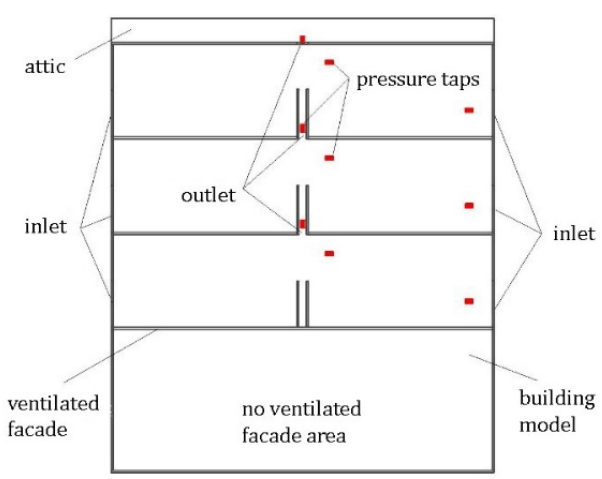

Fig. 4. Front view of the building model.

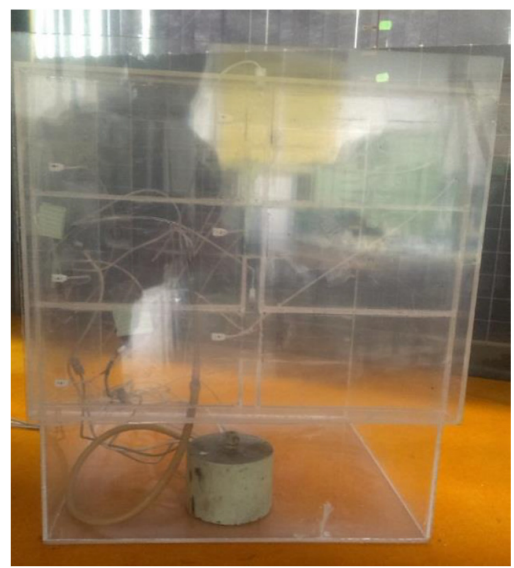

Fig. 5. Front view of the building model inside the wind tunnel.

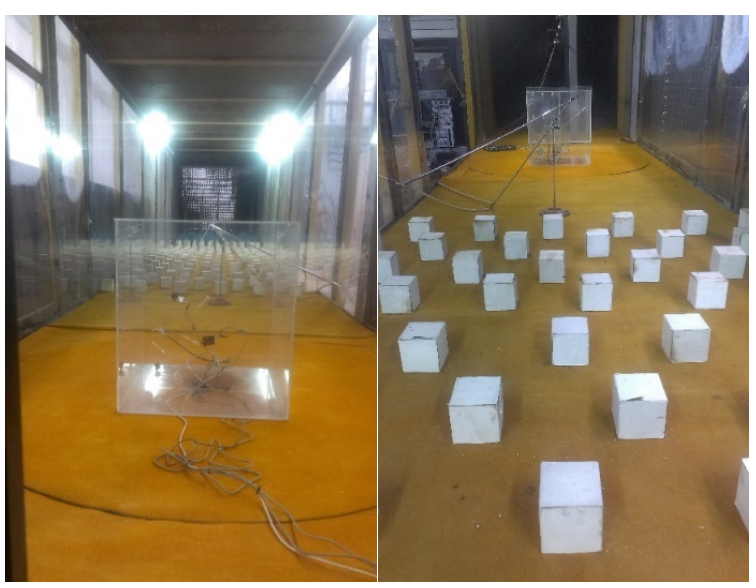

Fig. 6. Overview of the positioning of the model inside the wind tunnel and the rough elements for creating turbulence.

The wind tunnel system is $10 \mathrm{~m}$ length, being equipped with rough elements that are creating the turbulent boundary layer, Fig. 6 . In order to achieve the real wind conditions, the model of the building is placed at $6 \mathrm{~m}$ towards the turbulence grid of the tunnel.

During experimental tests, measurements of dynamic pressures and air speed were made, using the Pitot tube and a hot wire anemometer, Fig. 7. The measuring probes are placed at a $0.33 \mathrm{~m}$ height in the front of the model, equivalent to $10 \mathrm{~m}$ on the real building. This location will be referred during the study as the reference velocity point, $v_{r e f}$.

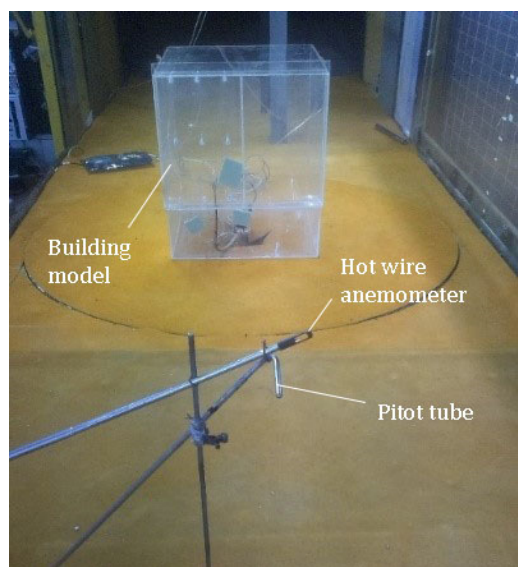

Fig. 7. Pitot tube and hot wire anemometer in the reference velocity point.

During the experimental study, the wind effect was tested for different reference velocities: 1, 2, 3, 4 and $5 \mathrm{~m} / \mathrm{s}$. The direction of the wind in the reference point is varied from normal $\left(0^{\circ}\right)$ to parallel $\left(90^{\circ}\right)$ to the channel of double skin façade of the building model, with a $30^{\circ}$ step as shown in Fig. 8. 


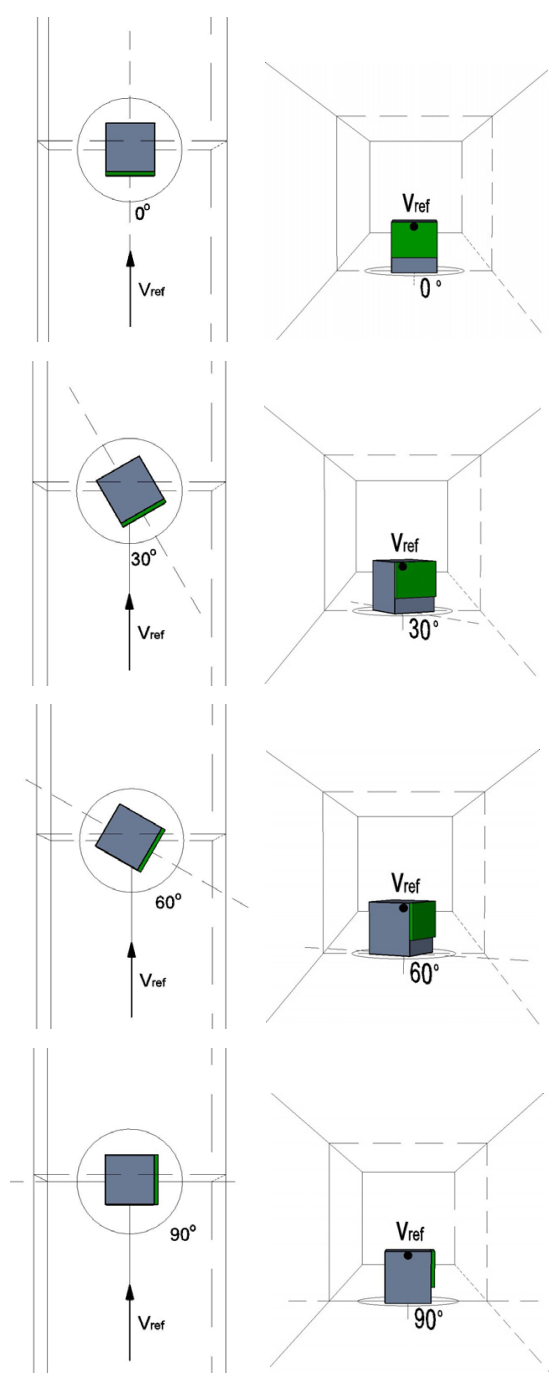

Fig. 8. Direction of the reference wind.

\section{Results}

The results are based on the assumption that in case of buildings model, characterized by sharp edges, it can be considered that the geometric similarity is sufficient for assuring the dynamic similarity. This hypothesis is available for Reynolds numbers superior to the turbulent flow limit, $5 \cdot 10^{5}$.

The experimental analysis was accomplished at $R e$ numbers according to Tab. 2. For the values obtained for reference velocities above $3 \mathrm{~m} / \mathrm{s}$ the assumption of the self-modelling is achieved for the studied model.

Table 2. Reynolds number depending on the reference velocity.

\begin{tabular}{|c|c|c|c|c|c|}
\hline $\boldsymbol{v}_{\text {ref }}[\mathbf{m} / \mathbf{s}]$ & $\mathbf{1}$ & $\mathbf{2}$ & $\mathbf{3}$ & $\mathbf{4}$ & $\mathbf{5}$ \\
\hline $\operatorname{Re}$ & 26444 & 52889 & 79333 & 105778 & 132222 \\
\hline
\end{tabular}

For obtaining an accurate interpretation of the phenomenon, for self-modelling conditions, the measured velocity values are quantified as dimensionless coefficients:

$$
c_{v}=\frac{v_{m}}{v_{r e f}}
$$

where, $v_{m}$ - average velocity of the air inside the channel of the ventilated façade $[\mathrm{m} / \mathrm{s}]$; point $[\mathrm{m} / \mathrm{s}]$.

$v_{r e f}$ - average velocity of the air in the reference

The $c_{v}$ coefficients express the wind effect over the natural circulation of the air through the double skin façade channel. For cases when reference velocities are higher than $3 \mathrm{~m} / \mathrm{s}$, the self-modelling of the process is noticed and the coefficients determined using Eq. 3 tend to become constant (Fig 9) on measuring points (Fig. 10).

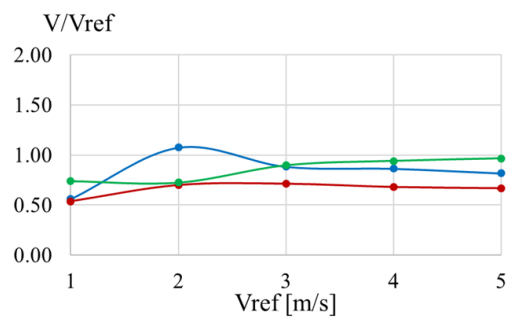

Fig. 9. Evolution of the $c_{v}$ coefficient depending on the reference velocity $v_{\text {ref. }}$

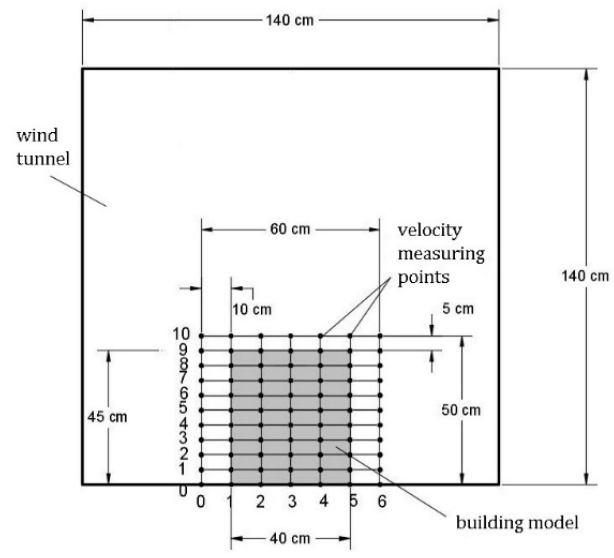

Fig. 10. Position of measuring points

Therefore, reaching self-modelling conditions, the results for the other velocities were neglected, the $c_{v}$ coefficients are calculated as the mean of three superior velocities $(3,4$ and $5 \mathrm{~m} / \mathrm{s})$. So, the $c_{v}$ values become very similar, with differences of less than $30 \%$ (Tab. 3).

The match ratio between these distributions for the reference velocity of $5 \mathrm{~m} / \mathrm{s}$ is presented in Table 3 . From $10 \mathrm{~cm}$ height above, the match is between 0.94 and 1.19 for the three reference velocities. This correspondence between experimental values and theoretical ones represents an important aspect and validates the results of the study.

The comparison of experimental results and theoretical law of the distribution of velocity showed some small differences for low level, but for heights of minimum $5 \mathrm{~cm}$ from the horizontal plane they become similar, Fig. 11. 
Table 3. Match ration between the distribution of measured velocities and theoretical exponential law $\left(v_{\text {ref }}=5 \mathrm{~m} / \mathrm{s}\right)$.

\begin{tabular}{|c|c|c|c|c|c|c|c|}
\hline $\begin{array}{c}\boldsymbol{d} \\
\boldsymbol{0}\end{array}$ & $\mathbf{0}$ & $\mathbf{1}$ & $\mathbf{2}$ & $\mathbf{3}$ & $\mathbf{4}$ & $\mathbf{5}$ & $\mathbf{6}$ \\
\hline $\mathbf{0}$ & 1,39 & 1,45 & 1,50 & 1,37 & 1,40 & 1,48 & 1,41 \\
\hline $\mathbf{1}$ & 1,38 & 1,37 & 1,29 & 1,32 & 1,28 & 1,37 & 1,37 \\
\hline $\mathbf{2}$ & 1,14 & 1,08 & 1,14 & 1,08 & 1,10 & 1,15 & 1,14 \\
\hline $\mathbf{3}$ & 1,00 & 1,01 & 1,02 & 1,01 & 0,98 & 1,04 & 1,02 \\
\hline $\mathbf{4}$ & 1,00 & 1,00 & 0,97 & 0,95 & 1,01 & 0,99 & 1,03 \\
\hline $\mathbf{5}$ & 0,96 & 0,96 & 1,01 & 0,95 & 0,96 & 1,03 & 1,03 \\
\hline $\mathbf{6}$ & 1,00 & 0,99 & 0,98 & 0,97 & 1,01 & 1,04 & 1,01 \\
\hline $\mathbf{7}$ & $\mathbf{1 , 0 0}$ & $\mathbf{1 , 0 0}$ & $\mathbf{1 , 0 0}$ & $\mathbf{1 , 0 0}$ & $\mathbf{1 , 0 0}$ & $\mathbf{1 , 0 0}$ & $\mathbf{1 , 0 0}$ \\
\hline $\mathbf{8}$ & 0,97 & 0,99 & 1,00 & 1,04 & 1,01 & 1,02 & 1,01 \\
\hline $\mathbf{9}$ & 0,96 & 1,01 & 1,02 & 1,05 & 1,04 & 1,02 & 1,00 \\
\hline $\mathbf{1 0}$ & 1,00 & 1,09 & 1,06 & 1,04 & 1,05 & 1,02 & 1,01 \\
\hline
\end{tabular}

where, $d$-horizontal measurement (distance from the axis of the wind tunnel) $[\mathrm{cm}]$;

$h$ - vertical measurement points (height above the floor of the wind tunnel) $[\mathrm{cm}]$.

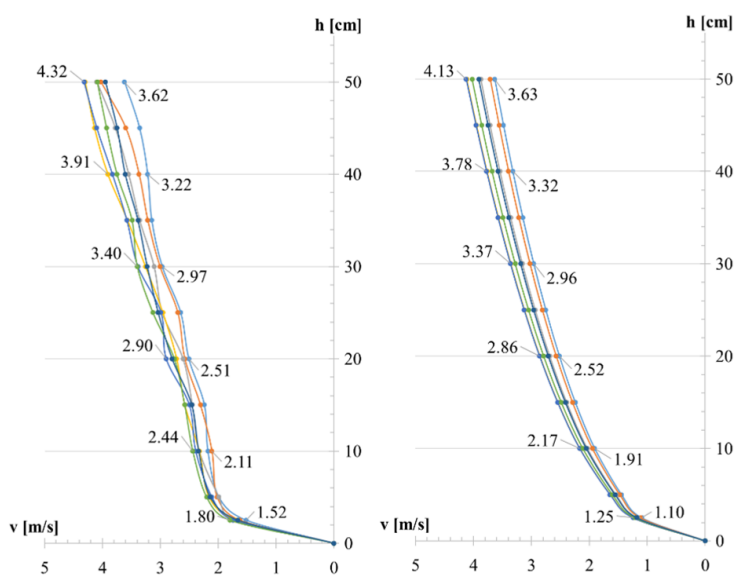

a)

b)

Fig. 11. Comparison between vertical distribution of the reference velocity of experimental data (a) and exponential distribution law (b) at $v_{\text {ref }}=5 \mathrm{~m} / \mathrm{s}$.

The exponential law of vertical distribution of the wind velocities is:

$$
v_{z}=v_{g} \cdot\left(\frac{z}{z_{g}}\right)^{\alpha}=v_{10} \cdot\left(\frac{z}{z_{10}}\right)^{\alpha}
$$

where, $v_{z}-$ wind velocity at height $z[\mathrm{~m} / \mathrm{s}]$;

$$
v_{g}-\text { gradient velocity }[\mathrm{m} / \mathrm{s}]\left(v_{g}=v_{10}\right) \text {; }
$$

$z$ - calculation height of the point $[\mathrm{m}]$;

$z_{g}-$ gradient height $[\mathrm{m}]\left(z_{g}=z_{10}=10 \mathrm{~m}\right)$;

$\alpha$ - coefficient of terrain.

The averaged values for $c_{v}$ coefficients for each wind direction are represented in Fig. 12 - Fig. 15, for all measuring points.

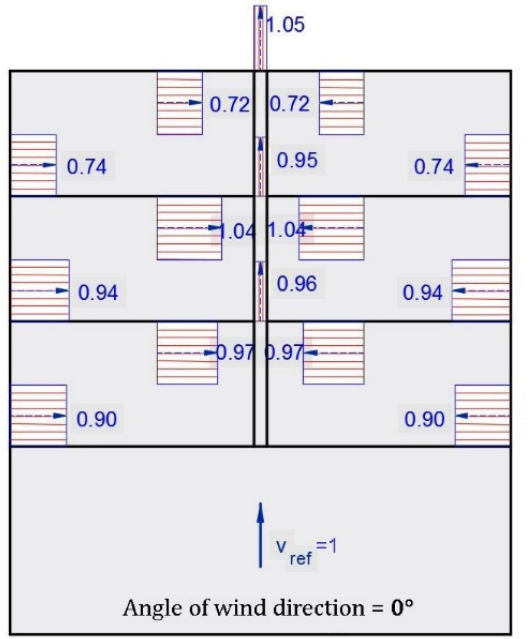

Fig. 12. $c_{v}$ coefficients determined in measuring points for $0^{\circ}$

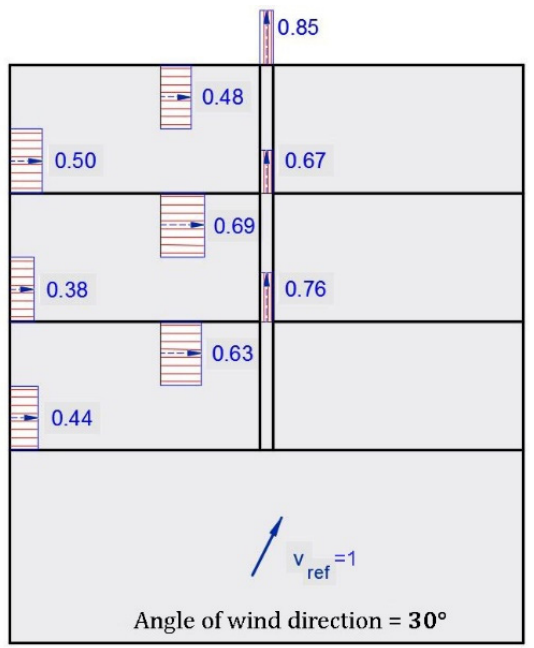

Fig. 13. $c_{v}$ coefficients determined in measuring points for $30^{\circ}$

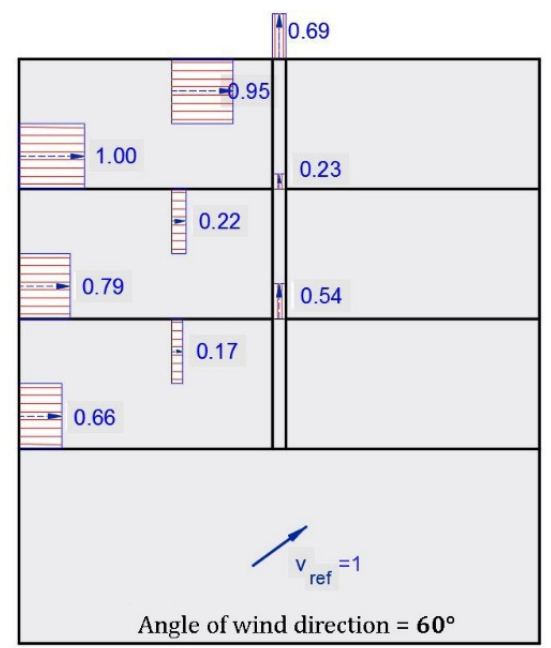

Fig. 14. $c_{v}$ coefficients determined in measuring points for $60^{\circ}$ 


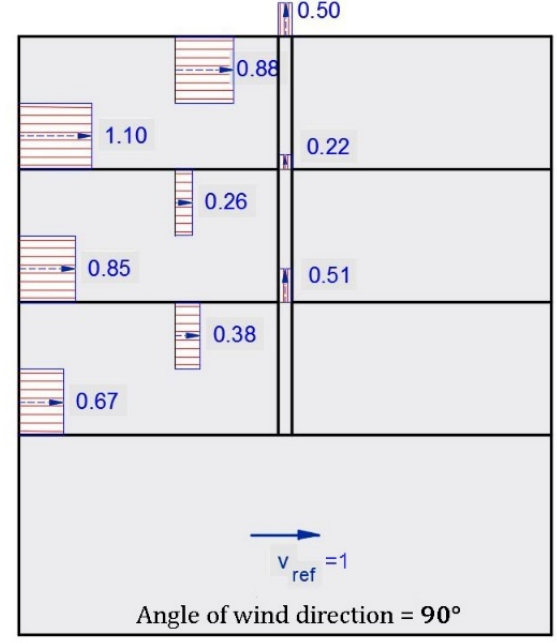

Fig. 15. $c_{v}$ coefficients determined in measuring points for $90^{\circ}$

The results regarding the $c_{v}$ coefficients of the velocities inside the channels conducted to the calculation of the convective heat transfer coefficients in the case of a real building, with the same geometrical characteristic as the modelled one.

Based on the $c_{v}$ values, the convective heat transfer coefficients, $h_{c}$, inside double skin façade channel, near PV panels were calculated according to Tab. 4.

Taking into account the annual average velocities in real conditions, the convective heat transfer coefficients were calculated for reference velocities between $0,5 \mathrm{~m} / \mathrm{s}$ and 3 $\mathrm{m} / \mathrm{s}$. Therefore, for this configuration of the double skin façade, the $h_{c}$ coefficients reach the values according to Tab. 4.

Table. 4. Heat transfer coefficients, $h_{c}$, inside the double skin façade channel.

\begin{tabular}{|c|c|c|c|c|c|c|}
\hline \multicolumn{7}{|c|}{$\boldsymbol{h}_{\boldsymbol{c}}\left[\mathbf{W} / \mathbf{m}^{\mathbf{2}} \mathbf{K}\right]$} \\
\hline $\begin{array}{c}\boldsymbol{v}_{\text {ref }} \\
{[\mathbf{m} / \mathbf{s}]}\end{array}$ & $\begin{array}{c}\mathbf{0}^{\circ} \\
\text { inf }\end{array}$ & $\begin{array}{c}\mathbf{0}^{\circ} \\
\text { med }\end{array}$ & $\begin{array}{c}\mathbf{0}^{\circ} \\
\text { sup }\end{array}$ & $\begin{array}{c}\mathbf{3 0}^{\circ} \\
\text { inf }\end{array}$ & $\begin{array}{c}\mathbf{3 0}^{\circ} \\
\text { med }\end{array}$ & $\begin{array}{c}\mathbf{3 0}^{\circ} \\
\text { sup }\end{array}$ \\
\hline 0,50 & 2,32 & $\mathbf{2 , 4 6}$ & 1,83 & 1,64 & 1,77 & 1,32 \\
\hline 1,00 & 4,04 & $\mathbf{4 , 2 8}$ & 3,19 & 2,86 & 3,08 & 2,30 \\
\hline 1,50 & 5,59 & $\mathbf{5 , 9 1}$ & 4,41 & 3,96 & 4,26 & 3,19 \\
\hline 2,00 & 7,04 & $\mathbf{7 , 4 5}$ & 5,55 & 4,99 & 5,36 & 4,01 \\
\hline 2,50 & 8,42 & $\mathbf{8 , 9 0}$ & 6,63 & 5,96 & 6,41 & 4,79 \\
\hline 3,00 & 9,74 & $\mathbf{1 0 , 3 0}$ & 7,67 & 6,90 & 7,42 & 5,55 \\
\hline
\end{tabular}

\begin{tabular}{|c|c|c|c|c|c|c|}
\hline \multicolumn{7}{|c|}{$\boldsymbol{h}_{\boldsymbol{c}}\left[\mathbf{W} / \mathbf{m}^{2} \cdot \mathbf{K}\right]$} \\
\hline $\begin{array}{c}\boldsymbol{v}_{\text {ref }} \\
{[\mathbf{m} / \mathbf{s}]}\end{array}$ & $\begin{array}{c}\mathbf{6 0}^{\circ} \\
\text { inf }\end{array}$ & $\begin{array}{c}\mathbf{6 0}^{\circ} \\
\text { med }\end{array}$ & $\begin{array}{c}\mathbf{6 0}^{\circ} \\
\text { sup }\end{array}$ & $\begin{array}{c}\mathbf{9 0}^{\circ} \\
\text { inf }\end{array}$ & $\begin{array}{c}\mathbf{9 0}^{\circ} \\
\text { med }\end{array}$ & $\begin{array}{c}\mathbf{9 0}^{\circ} \\
\text { sup }\end{array}$ \\
\hline 0,50 & 0,58 & 0,71 & 2,28 & 1,10 & 0,81 & 2,15 \\
\hline 1,00 & 1,00 & 1,23 & 3,98 & 1,91 & 1,41 & 3,74 \\
\hline 1,50 & 1,39 & 1,71 & 5,50 & 2,64 & 1,95 & 5,17 \\
\hline 2,00 & 1,75 & 2,15 & 6,93 & 3,33 & 2,46 & 6,51 \\
\hline 2,50 & 2,09 & 2,57 & 8,28 & 3,98 & 2,94 & 7,79 \\
\hline 3,00 & 2,42 & 2,97 & 9,58 & 4,60 & 3,40 & 9,01 \\
\hline
\end{tabular}

For the usual air velocities recorded close to buildings, $0.5 \ldots 3.0 \mathrm{~m} / \mathrm{s}$, the heat transfer coefficient inside the double skin façade channel achieve maximum values of about $2.46 \ldots 10.30 \mathrm{~W} / \mathrm{m}^{2} \cdot \mathrm{K}$ in the median channel.
The analysis of the cooling impact over the integrated photovoltaic panels is based on the temperature effect over their efficiency [20]. A typical efficiency of the photovoltaic effect of $16 \%$ is considered, for solar radiation of $1000 \mathrm{~W} / \mathrm{m}^{2}$. Given that in the present study the photovoltaics integration is realized on vertical surface (exterior layer of the double skin façade), a 500 $\mathrm{W} / \mathrm{m}^{2}$ nominal solar radiation can be considered [20]. In order to simplify the interpretation of the results, all data are related to a $1 \mathrm{~m}^{2}$ monocrystalline PV panel.

The power produced by the PV panel, at $500 \mathrm{~W} / \mathrm{m}^{2}$ and $25^{\circ} \mathrm{C}$ is about $73.4 \mathrm{~W} / \mathrm{m}^{2}$. The influence of cooling is calculated by taking into consideration an overall effect of the temperature over the efficiency of $-0.45 \% / C[20,21]$. The solar radiation effect used in calculation has a value of $1,66 \% / 100 \mathrm{~W} / \mathrm{m}^{2}$ at $500 \mathrm{~W} / \mathrm{m}^{2}$.

Therefore, for the base case, when the PV panel is integrated in the façade without ventilation, an operating temperature of $75^{\circ} \mathrm{C}$ can be achieved. This temperature reduces the maximum power generated by PV panel to $77.5 \%$ of the nominal one. In Tab. 5 is presented the effect of the cooling the PV panel for common reference velocities recorded near buildings.

Table 5. Effect of cooling over the PV panel's efficiency

\begin{tabular}{|c|c|c|c|c|}
\hline Case & $\begin{array}{c}\text { Base } \\
\text { case }\end{array}$ & $\begin{array}{c}v=0.5 \\
{[\mathrm{~m} / \mathrm{s}]}\end{array}$ & $\begin{array}{c}v=1,0 \\
{[\mathrm{~m} / \mathrm{s}]}\end{array}$ & $\begin{array}{c}v=1.5 \\
{[\mathrm{~m} / \mathrm{s}]}\end{array}$ \\
\hline$t\left[{ }^{\circ} \mathrm{C}\right]$ & 75 & 70.9 & 64.1 & 57.8 \\
\hline$[\%]$ of $P_{N}$ & 77.5 & 79.3 & 82.4 & 85.2 \\
\hline$\eta[\%]$ & 11.37 & 11.64 & 12.09 & 12.50 \\
\hline$P_{\text {gen }}[\mathrm{W}]$ & 14.22 & 14.56 & 15.12 & 15.64 \\
\hline Improvement $[\%]$ & - & 2.39 & 6.34 & 10.00 \\
\hline
\end{tabular}

\section{Conclusions}

The experimental results have revealed the effect of the wind over the air circulation and velocities magnitude inside double skin façade channel in the near vicinity of the photovoltaic panels. The air flow inside the double skin façade is predominantly vertical and horizontal, which represents an important aspect in order to avoid the vertical overheating and extreme thermal draft effect during summer.

The results showed that the best wind direction for the analyzed double skin façade is the normal one $\left(0^{\circ}\right)$, assuring the best cooling conditions for PV panels and a raise in efficiency and energy generated.

The results, quantified as $c_{v}$ coefficients, showed that the average velocity of the air near the exterior glazing of the double skin façade is dependent on the reference velocity, $v_{r e f}$, and has the same order of magnitude. The $c_{v}$ coefficients in the median area of the façade, for the $0^{\circ}$ angle of wind direction, reach average values between $0.95 \ldots 1.05$. For the inlet and outlet sections, these coefficients are laying between $0.74 \ldots 0.97$.

The double skin façade system is very suitable for building integrated photovoltaic solutions. Therefore, a combination of aesthetics and efficiency is achieved. The cooling effect of natural ventilation of channel, by wind 
action, revealed a possible increase of the generated electric power between $2.39 \ldots 10.00 \%$ compared to the base case.

\section{References}

1. Vasan N., Stathopoulos T., Wind Tunnel Assessment of the Wind Velocity Distribution on Vertical Façades, Proceedings of eSim, 2012, pp. 61-74.

2. Quirouette R., Arch B., La pression d'air et l'envelope du batiment, Ontario Association of Architects, 2004.

3. Axinte E., Teleman E. C., Băetu G., Pescaru R. A., Silion R., Studies for preventing the impact of climate changes upon built environment, The Bulletin of the Polytechnic Institute of Jassy, CA Section, Tome: LXI (LXV), 2015, pp. 61-74.

4. Flamand O., Action du vent sur les ouvrages Effets dynamiques, Universite de Nantes.

5. Axinte E., Pescaru R. A., Studiul acțiunii vântului în tunel aerodinamic, Editura Cermi, Iași, Romania, 2000.

6. Sacht H., Bragança L., Almeida M., Caram R., Study of natural ventilation in wind tunnels and influence of the position of ventilation modules and types of grids on a modular façade system, Energy Procedia 96 (2016) 953 - 964.

7. http://rlsenergy.com/wpcontent/uploads/2012/11/Wind_Speed_Increase Height.gif

8. Loua W., Huang M., Zhang M., Lin N., Experimental and zonal modeling for wind pressures on double-skin facades of a tall building, Energy and Buildings, Vol. 54, 2012, pp.179-191.

9. Hudișteanu, S.V., Mateescu, T.D., Ciocan, V., Teleman, C., Băetu, G., Wind tunnel investigation of natural ventilation inside double skin façades, International Multidisciplinary Scientific GeoConference Surveying Geology and Mining Ecology Management, SGEM, Volume 17, Issue 42, 2017, Pages 691-69.

10. Hudişteanu, S.V., Popovici, C.G., Cherecheş, N.-C., Wind tunnel study of natural ventilation of building integrated photovoltaics double skin façade, E3S Web of Conferences, Volume 32, 21 February 2018, Article number 01020

11. Kawai H., Nishimura H., Suzuki M., Oura Y., Field Measurement of Wind Pressure on a Double Skin with a Ventilator, EACWE 5 Florence, 12 pages, 2009.

12. Silva F.M., Gomes M.G., Rodrigues A.M., Measuring and estimating airflow in naturally ventilated double skin facades, Building and Environment, Vol. 87, 2015, pp. 292-301.

13. Tominaga Y., Blocken B., Wind tunnel experiments on cross-ventilation flow of a generic building with contaminant dispersion in unsheltered and sheltered conditions, Building and Environment, Vol. 92, 2015, pp. 452-461.

14. Barbosa S., Ip K., Perspectives of double skin façades for naturally ventilated buildings: A review, Renewable and Sustainable Energy Reviews, Vol. 40, 2014, pp. 1019-1029.

15. Agathokleous R.A., Kalogirou S.A., Double skin facades (DSF) and building integrated photovoltaics (BIPV): A review of configurations and heat transfer characteristics, Renewable Energy Vol. 89, 2016, pp. 743-756.

16. Sacht H., Bragança L., Almeida M., Caram R., Different module placements in a modular façade system for natural ventilation, Economics and Finance, Vol. 21, 2015, pp. 366-373.

17. Gaillard L., Ruedin, G. Giroux, Plantevit M., Kaytoue M., Saadon S., Ménézo C., Boulicaut J.F., Data-driven performance evaluation of ventilated photovoltaic double-skin facades in the built environment, Energy Procedia, Vol. 78, 2015, pp 447-452.

18. Hudișteanu S.V., Popovici C.G., Mateescu T.D., Cherecheș N.-C., Efficiency analysis of BIPV systems for different locations in Romania, Energy Procedia, Vol. 112, 2017, pp. $404-411$.

19. Neff D.E., Meroney N.R., Reynolds number independence of the wind tunnel simulation of transport and dispersion about buildings, Colorado State University, 20 pages, 1996.

20. Popovici C.-G, Hudişteanu, S. V., Mateescu T. D., Cherecheş N.-C., (2016), Efficiency improvement of PV panels by using air cooled heat sinks, Energy Procedia, 85, 425-432.

21. Popovici C.-G., Cirlan V.V., Mateescu T.D., Chereches N.-C., Hudisteanu S.V., Influence of various angles of the venetian blind on the efficiency of a double skin façade, Energy Procedia 85 (2016) 416 - 424. 